\title{
KEPASTIAN HUKUM BAGI WARGA NEGARA INDONESIA DALAM PEMBUATAN SURAT KETERANGAN WARIS
}

\author{
Michael Hartono \\ Fakultas Hukum Universitas Brawijaya Malang \\ Malang, Jawa Timur, Indonesia \\ Email: contactmichahartono@gmail.com
}

\begin{abstract}
Abstrak
Ketidakpastian hukum bagi Warga Negara Indonesia dalam pembuatan Surat Keterangan Waris yang dasar hukumnya masih menerapkan konsep penggolongan penduduk. Tesis ini menggunakan metode yuridis normatif, dengan metodek pendekatan perundang-undangan (statute approach), pendekatan konsep (conceptual approach), dan pendekatan sejarah (historicalapproach). Bahanhukumprimer, sekunder, dantersieryang diperoleh penelitiakan dianalisis dengan menggunakan teknik analisis deskriptif-analitis, yaitu mendeskripsikan atau menguraikan bahan hukum yang diperoleh, kemudian menggambarkan permasalahan hukum yang ada secara sistematis, sehingga dapat ditarik kesimpulan bagi pemecahan masalah dalam penelitian hukum ini.Semenjak diberlakukannya Undang-undang Republik Indonesia Nomor 12 Tahun 2006 Tentang Kewarganegaraan Republik Indonesia dan Undang-Undang Republik Indonesia Nomor 24 Tahun 2013 Tentang Perubahan Atas Undang-Undang Nomor 23 Tahun 2006 Tentang Administrasi Kependudukan yang tidak lagi mengenal adanya penggolongan penduduk Indonesia, menurut hukum Pasal 111 Ayat (1) Huruf C Angka 4 Peraturan Menteri Negara Agraria / Kepala Badan Pertanahan Nasional No. 3 Tahun 1997 tentang Ketentuan Pelaksanaan Peraturan Pemerintah No. 24 Tahun 1997 tentang Pendaftaran Tanah tidak berlaku lagi pada saat ini.
\end{abstract}

\section{Kata Kunci: Kepastian hukum; Penggolongan Penduduk Indonesia; Surat Keteran-} gan Waris

\begin{abstract}
The legal uncertainity is happening For Indonesian Citizens in the making of Inheritance Sertificate whose a legal basis still applies the concept of population. This thesis uses the yuridical normative method, with the approaches of statute approach, conceptual approach, and historical approach. Primary, secondary, and tertiary legal materials obtained by the writer will be analyzed using a descriptive-analytic analysis technique, which is describing or deciphering the obtained legal materials, then describing the legal issues sistematically, thus to pull out a conclusion as a way of solving the problem in this legal study. Since the enactment of Constituional Law Number 12 Year 2006 About the Citizenship of the Republic of Indonesia and the Constitutional Law Number 24 Year 2013 About Amendments Of Constitutional Law Number 23 Year 2006 About Population Administration that no longer recognizes classifications of Indonesian citizens, according to the law Chapter 111 Verse (1) Alphabet C Digit 4 Agrarian Country Ministerial Regulation / Head of National Land Agency Number 3 Year 1997 about the Implementing Provisions of Ministerial Regulation Number 24 Year 1997 about Land Registration is no longer applicable at this time.
\end{abstract}

Keywords: Legal Certainity; Indonesian Citizens ClassificationsInheritance Sertificate 


\section{A. PENDAHULUAN}

Peristiwa hukum adalah semua peristiwa atau kejadian yang dapat menimbulkan akibat hukum, antara pihak yang mempunyai hubungan hukum ${ }^{1}$. Terdapat beberapa macam peristiwa hukum yang penting bagi manusia dalam kehidupannya, meliputi peristiwa hukum kelahiran, perkawinan, dan peristiwa hukum kematian. Peristiwa hukum kematian tidak bisa terlepas dari akibat-akibat hukum selanjutnya yang timbul, salah satunya terkait dengan bagaimana proses pengurusan dan kelanjutan hak-hak dan kewajiban-kewajiban seseorang yang meninggal dunia tersebut ${ }^{2}$.

Hukum waris di Indonesia masih bersifat pluralistis $^{3}$, yang mana pluralistis dalam hukum waris Indonesia hingga saat ini dapat terlihat dari keadaan dimana hingga saat ini masih diberlakukan tiga sistem hukum kewarisan, yang meliputi Hukum Waris berdasarkan Hukum Adat, Hukum Waris berdasarkan Hukum Agama Islam, dan Hukum Waris berdasarkan Hukum Perdata/ Burgerlijk Wetboek voor Indonesie (BW). Masih berlakunya Sistem Hukum Waris berdasarkan Hukum Perdata/ Burgerlijk Wetboek voor Indonesie (BW) tidak bisa dilepaskan dari masih diberlakukannya penggolongan-penggolongan penduduk di Indonesia seperti diatur dalam Pasal 163 yang menetapkan tiga golongan penduduk Indonesia (dahulu Hindia Belanda), yang meliputi : 4

1. Golongan Eropa, yaitu orang-orang Belanda, Jerman, Inggris, Perancis, serta orang-orang Jepang, Amerika Serikat, Australia, dan Kanada;

${ }^{1}$ Soedjono Dirdjosisworo. (2018). Pengantar Ilmu Hukum, Depok: PT. Raja Grafindo Persada, hlm. 128.

${ }^{2}$ Mohd. Idris Ramulyo. (1982). "Suatu Perbandingan antara Ajaran Sjafi'I dan Wasiat Wajib di Mesir, tentang pembagian Harta Warisan untuk Cucu Menururt Islam”. Majalah Hukum dan Pembangunan No. 2 Thn. XII,154.

${ }^{3}$ Surini Ahlan Sjarif dan Nurul Elmiyah. (2014). Hukum Kewarisan Perdata Barat: Pewarisan Menurut Undang-Undang, Jakarta: Kencana Prenadamedia Group, hlm. 1.

${ }^{4}$ Mohd. Idris Ramulyo. (1996). Beberapa Masalah Pelaksanaan Hukum Kewarisan Perdata Barat (Burgerlijk Wetboek), Jakarta: Sinar Grafika, hlm. 13-14.
2. Golongan Timur Asing, yang dalam perkembangannya dibedakan menjadi 2 (dua) yaitu orang-orang Tionghoa, dan orang-orang bukan Tionghoa (meliputi orang-orang Arab, India, Pakistan, Muangthai, dan orang-orang Timur Asing lainnya);

3. Golongan Bumi Putera, yaitu orang-orang Indonesia asli yang terdiri atas 19 Kukuban HukummenurutProf. Van Vollenhoven, dan Ter Haar.

Masih diberlakukannya praktik penggolongan penduduk tersebut diatas telah menimbulkan banyak sekali perdebatanperdebatan terkait keberlakuannya. Belum adanya Hukum Waris yang bersifat nasional di Indonesia dapat menimbulkan ketidakpastian hukum. Secara norma hukum, keabsahan pembuatan Surat Keterangan Waris (SKW) sangatlah penting bagi seorang Ahli Waris agar mendapatkan hak dan kewajiban atas harta warisan yang ditinggalkan oleh Pewaris yang telah meninggal dunia. Pembuatan Surat Keterangan Waris itu sendiri berbedabeda pihak yang berwenang membuatnya, diantaranya adalah $:^{5}$

1. Penguatan oleh Kepala Desa/Kelurahan dan Camat tempat tinggal pewaris pada waktu meninggal dunia bagi warganegara Indonesia penduduk asli;

2. Oleh Notaris bagi warganegara Indonesia keturunan Tionghoa;

3. Oleh Balai Harta Peninggalan bagi warganegara Indonesia keturunan Timur Asing lainnya.

Dalam perkembangannya Undangundang Republik Indonesia Nomor 12 Tahun 2006 Tentang Kewarganegaraan Republik Indonesia (UU Kewarganegaraan) hanya mengenal istilah Warga Negara Indonesia, dan Warga Negara Asing. Berdasarkan halhal tersebut diatas timbul keadaan dimana norma-norma hukum positif di Indonesia saling bertentangan satu sama lain, yang

${ }^{5}$ Pasal 111 Ayat (1) Huruf C Angka 4 Peraturan Menteri Negara Agraria / Kepala Badan Pertanahan Nasional No. 3 Tahun 1997 tentang Ketentuan Pelaksanaan Peraturan Pemerintah No. 24 Tahun 1997 tentang Pendaftaran Tanah. 
mana dapat menimbulkan ketidakpastian hukum dalam pembuatan Surat Keterangan Waris.

\section{B. METODE PENELITIAN}

Jenis penelitian yang dipergunakan oleh peneliti adalah yuridis normatif, yaitu suatu proses untuk menemukan suatu aturan hukum, prinsip hukum, maupun doktrin-doktrin hukum untuk menjawab permasalahan hukum yang dihadapi dan dilakukan untuk menghasilkan argumentasi, teori atau konsep baru sebagai preskripsi dalam menyelesaikan masalah yang dihadapi. Sesuai dengan karakter keilmuan hukum normatif yang menitikberatkan pada telaah "hukum atau kajian hukum (rechtsboefening) terhadap hukum positif'. Pertimbangan Peneliti dalam mempergunakan jenis penelitian ini adalah untuk mendeskripsikan dan menganalisis kedudukan Pasal 163 Indische Staatsregeling terkait dengan pembuatan Surat Keterangan Waris, serta untuk menganalisis kepastian hukum dalam pembuatan Surat Keterangan Waris yang masih didasarkan pada Pasal 163 Indische Staatsregeling.

Dalam penelitian yuridis normatif ini peneliti menggunakan beberapa macam metode pendekatan penelitian, diantaranya adalah:

\section{Pendekatan perundang-undangan (stat- ute approach)}

Pendekatan perundang-undangan (statute approach) secara otomatis dipergunakan karena menurut peneliti peraturan perundangundangan merupakan titik fokus utama dari suatu penelitian yuridis normatif. Sehingga dalam penelitian ini peneliti menganalisa atau menelaah berbagai peraturan perundangundangan dan bahan hukum yang terkait dengan pembuatan Surat Keterangan Waris bagi Warga Negara Indonesia. Untuk mengetahui ratio legis dari berbagai peraturan perundang-undangan, dan bahan hukum tersebut, peneliti melakukan metode interpretasi atau penafsiran, yang mana tujuannya adalah menelusuri hukum positif negara sebagai sumber hukum positif normanorma peraturan perundang-undangan negara. Jenis interpretasi yang peneliti gunakan ialah interpretasi teleologis (sosiologis) yang merupakan bentuk penafsiran secara hukum untuk mengetahui tujuan adanya berbagai peraturan perundang-undangan dan bahan hukum tersebut, yang menjadi bahan hukum peneliti dalam penelitian hukum ini.

\section{Pendekatan konsep (conceptual ap- proach)}

Pendekatan konsep (conceptual approach) diawali dengan pandangan-pandangan dan doktrin-doktrin oleh para ahli hukum yang berkembang dalam ilmu hukum. Dengan mempelajari hal-hal tersebut, akan ditemukan ide-ideyangmelahirkanpengertian-pengertian hukum, konsep-konsep hukum dan asas-asas hukum yang relevan dengan permasalahan yang diteliti, serta dengan pendekatan konsep itu pula dapat dibuat argumentasi hukum dalam menjawab permasalahan hukum yang diajukan. Lewat pendekatan konsep peneliti mencoba untuk melihat konsep awal terkait pembedaan golongan-golongan penduduk berdasarkan Pasal 163 Indische Staatsregeling, dan kaitannya dengan pihakpihak yang berwenang melakukan pembuatan Surat Keterangan Waris bagi Warga Negara Indonesia.

\section{Pendekatan sejarah (historical ap- proach)}

Pendekatan sejarah digunakan peneliti dengan menganalisa dan menelaah latar belakang dan perkembangan dari materi yang diteliti. Penelitian hukum normatif yang menggunakan pendekatan sejarah memungkinkan "seorang peneliti untuk memahami hukum secara lebih mendalam tentang suatu sistem atau lembaga, atau suatu pengaturan hukum tertentu, sehingga dapat memperkecil kekeliruan, baik dalam pemahaman maupun penetapan suatu lembaga atau ketentuan hukum tertentu". Dengan demikian, diharapkan melalui 
pendekatan sejarah peneliti dapat mengetahui dan mempelajari sejarah dari dibuatnya aturan terkait pembedaan golongangolongan penduduk berdasarkan Pasal 163 Indische Staatsregeling, serta mengetahui dan mempelajari sejarah dibuatnya aturan terkait dengan pihak-pihak yang berwenang melakukan pembuatan Surat Keterangan Waris bagi Warga Negara Indonesia. Dengan mengetahui dan mempelajari dibuatnya kedua aturan diatas diharapkan dapat membantu peneliti untuk memperoleh pemahaman yang lebih mendalam untuk menjawab rumusan masalah yang telah diajukan oleh peneliti.

Teknik pengumpulan bahan hukum, baik primer, sekunder dan tersier dilakukan peneliti melalui studi kepustakaan (library research) dan studi dokumen (document research), yaitu dengan cara mempelajari dan mencatat data dari bahan pustaka yang telah dikumpulkan. Selanjutnya hasilnya dikumpulkan untuk dianalisis dan diambil kesimpulannya sesuai dengan pokok permasalahan yang telah Peneliti kemukakan sebelumnya dalam rumusan masalah.

Bahan hukum yang diperoleh melalui studi kepustakaan, aturan perundangundangan, artikel hukum dan sebagainya dihubungkan sedemikian rupa sehingga peneliti dapat menyajikannya dalam bentuk tulisan yang lebih sistematis untuk menjawab permasalahan yang telah dirumuskan. Pengolahan dan analisis bahan-bahan hukum tersebut diatas dilakukan melalui metode analisis preskriptif. Ilmu hukum preskriptif merupakan ilmu yang mempelajari tujuan hukum, nilai-nilai keadilan, validitas aturan hukum, konsep-konsep hukum dan normanorma hukum.

Untuk penelitian ini interpretasi yang digunakan diantaranya adalah

\section{a. Interpretasi Historis}

Para hakim yang bermaksud mengetahui makna kata atau kalimat dalam suatu Undang-undang misalnya, dia harus menafsirkan dengan jalan meneliti sejarah kelahiran pasal tertentu itu dirumuskan.
Ada dua macam interpretasi historis, yaitu: Pertama, interpretasi menurut sejarah pengaturannya atau sejarah Undangundangnya (wetshistorisch) adalah mencari maksud dari perundang-undangan itu seperti apa, dalam hal ini dilihat dari pembuat Undang-Undangnya. Jadi dalam interpretasi ini, kehendak pembentuk Undang-undang itu sangat menentukan. Kedua, interpretasi menurut sejarah kelembagaan hukumnya atau sejarah hukumnya (rechtshistorisch) adalah metode interpretasi yang ingin memahami Undang-undang dalam konteks seluruh sejarah hukumnya, khususnya yang terkait dengan kelembagaan hukumnya.

\section{b. Interpretasi Sistematis}

Merupakan metode yang menafsirkan Undang-undang sebagai bagian dari keseluruhan sistem perundang-undangan. Artinya tidak satupun dari peraturan perundangan tersebut dapat ditafsirkan seakan-akan ia berdiri sendiri, tetapi ia harus selalu dipahami dalam kaitannya dengan jenis peraturan yang lainnya. Menafsirkan peraturan perundangan tidak boleh menyimpang atau keluar dari sistem perundang-undangan suatu negara.

\section{c. Interpretasi Sosiologis atau Teleologis}

Yaitu apabila makna Undangundang ditetapkan berdasarkan tujuan kemasyarakatannya. Melalui interpretasi ini hakim dapat menyelesaikan adanya perbedaan atau kesenjangan anatara sifat positif dari hukum (rechtspositiviteit) dengan kenyataan hukum (rechtswerkelijkheid), sehingga jenis interpretasi sosiologis dan teleologis menjadi sangat penting. Sebagai contoh ada sebuah Undang-undang yang masih berlaku, tetapi sebenarnya jiwanya sudah usang dan tidak sesuai dengan perkembangan dan kebutuhan zaman. Kemudian berdasarkan interpretasi sosiologis/teleologis Undang-undang ini kenyataannya masih diterapkan terhadap peristiwa atau kasus masa kini, maka sudah barang tentu sebenernya Undang-undang itu tidak layak lagi dijadikan dasar pertimbangan 
hukum oleh hakim dan kalaulah dipaksakan penerapannya akan terjadi pemerkosaan hukum dan rasa keadilan masyarakat.

Pada akhirnya penelitian dilakukan untuk menghasilkan argumentasi, teori, atau konsep baru sebagai preskripsi berdasarkan argumentasi yang sudah dibangun, yang diharapkan dapat menjadi pertimbangan dalam pemecahan masalah hukum yang dihadapi dalam penelitian ini, yaitu tentang bagaimanakah bentuk konstruksi kepastian hukum bagi Warga Negara Indonesia dalam pembuatan Surat Keterangan Waris, mengingat masih adanya conflict of norm antara Pasal 111 Ayat (1) Huruf C Angka 4 Peraturan Menteri Negara Agraria/ Kepala Badan Pertanahan Nasional No. 3 Tahun 1997 tentang Ketentuan Pelaksanaan Peraturan Pemerintah No. 24 Tahun 1997 tentang Pendaftaran Tanah dengan Undangundang Republik Indonesia Nomor 12 Tahun 2006 Tentang Kewarganegaraan Republik Indonesia dan Undang-Undang Republik Indonesia Nomor 24 Tahun 2013 Tentang Perubahan Atas Undang-Undang Nomor 23 Tahun 2006 Tentang Administrasi Kependudukan.

\section{PEMBAHASAN}

\section{Sejarah Penggolongan Penduduk Di In- donesia Yang Mempengaruhi Dasar Hu- kum Pembuatan Surat Keterangan Waris}

Dasar hukum pembuatan surat keterangan waris berdasarkan politik hukum penggolongan penduduk sesuai dengan Pasal 163 Indische Staatsregeling berkaitan dengan sejarah berlakunya Kitab Undang-undang Hukum Perdata (KUHPerdata)/ Burgerlijk Wetboek voor Indonesie (BW) di Indonesia.

Hukum perdata yang berbentuk tertulis dan diberlakukan di Indonesia hingga saat ini merupakan bentuk produk hukum yang dikeluarkan oleh pemerintahan kolonial Belanda berdasarkan civil law system. Pasal 163 Indische Staatsregeling sebagai dasar hukum penggolongan penduduk di Indonesia diawali dengan masih dikenalnya dua atau empat golongan penduduk berdasarkan aturan hukum yang terdapat didalam Algemene Bepalingen van Wetgeving voor Indonesie (AB) Stb. 1847 Nomor 23, yang diberlakukan sejak tanggal 1 Mei 1848.

Setelah sistem penggolongan penduduk yang diterapkan pada masa Algemene Bepalingen van Wetgeving voor Indonesie (AB) berakhir, kemudian dilanjutkan dengan sistem pembagian penggolongan penduduk berdasarkan Regerings Reglement (RR), yang diterapkandaritahun 1855-1920. Secaraumum pada masa RR penggolongan penduduk masih mengadopsi sistem penggolongan penduduk yang diterapkan sebelumnya pada masa $\mathrm{AB}$, yaitu penduduk digolongkan tetap menjadi 2 (dua) atau 4 (empat) golongan penduduk. Setelah masa RR tersebut berakhir, maka muncul masa baru, yaitu masa berlakunya Indische Staatsregeling (IS) Stb. 1925 No. 415 , yang diberlakukan mulai dari tanggal 1 Januari 1926. Berdasarkan hal tersebut diatas dapat dilihat bahwa asal-usul dari lahirnya IS yang secara historis merupakan terapan dari aturan penggolongan penduduk dalam masa Regerings Reglement (RR). Pasal 163 Indische Staatsregeling tersebut diatas yang hingga saat ini masih menjadi dasar norma hukum penggolongan penduduk Indonesia menjadi 3 (tiga) golongan penduduk, yang mana hal tersebut diatas mempengaruhi pula dasar hukum terkait pembedaan pihakpihak yang berwenang dalam pembuatan surat keterangan waris di Indonesia yang didasarkan pada golongan-golongan penduduk, yang diatur dalam Pasal 111 Ayat (1) Huruf C Angka 4 Peraturan Menteri Negara Agraria/ Kepala Badan Pertanahan Nasional No. 3 Tahun 1997 tentang Ketentuan Pelaksanaan Peraturan Pemerintah No. 24 Tahun 1997 tentang Pendaftaran Tanah, dimana lahirnya aturan tersebut juga tidak dapat dilepaskan dari pengaruh besar politik hukum pertanahan atau agraria. Beberapa ahli hukum di Indonesia memiliki pendapat hukum bahwa Pasal 111 Ayat (1) Huruf C Angka 4 Peraturan Menteri Negara Agraria 
/ Kepala Badan Pertanahan Nasional No. 3 Tahun 1997 tentang Ketentuan Pelaksanaan Peraturan Pemerintah No. 24 Tahun 1997 tentang Pendaftaran Tanah tersebut telah bertentangan denganasas-asas yang ditetapkan dalam UUPA. Masih diterapkannya aturan hukum yang membedakan pihak-pihak yang berwenang membuat Surat Keterangan Waris bagi Warga Negara Indonesia yang masih didasarkan pada prinsip hukum kolonial yaitu berdasarkan golongan-golongan penduduk telah bertentangan dengan salah beberapa poin dalam unsur filosofis lahirnya Undangundang Nomor 5 Tahun 1960 Tentang Peraturan Dasar-Dasar Pokok Agraria yaitu:

b. bahwa hukum agraria yang masih berlaku sekarang ini sebagian tersusun berdasarkan tujuan dan sendi-sendi dari pemerintahan jajahan dan sebagian dipengaruhi olehnya, hingga bertentangan dengan kepentingan rakyat dan Negara di dalam menyelesaikan revolusi nasional sekarang ini serta pembangunan semesta;

d. bahwa bagi rakyat asli hukum agraria penjajahan itu tidak menjamin kepastian hukum;

Penjelasan Umum UUPA BAB III (Dasardasar untuk mengadakan kesatuan dan kesederhanaan hukum) Angka (2) yang menyebutkan bahwa:

(2) "Di dalam menyelenggarakan kesatuan hukum itu Undang-Undang Pokok Agraria tidak menutup mata terhadap masih adanya perbedaan dalam keadaan masyarakat dan keperluan hukum dari golongan-golongan rakyat. Berhubung dengan itu ditentukan dalam pasal 11 ayat 2, bahwa: "Perbedaan dalam keadaan masyarakat dan keperluan hidup golongan rakyat di mana perlu dan tidak bertentangan dengan kepentingan nasional di perhatikan". Yang dimaksud dengan perbedaan yang didasarkan atas golongan rakyat misalnya perbedaan dalam keperluan hukum rakyat kota dan rakyat pedesaan, pula rakyat yang ekonominya kuat dan rakyat yang lemah ekonominya. Maka ditentukan dalam ayat 2 tersebut selanjutnya, bahwa dijamin perlindungan terhadap kepentingan golongan yang ekonomi lemah".

Berlakunya Pasal 111 Ayat (1) Huruf C Angka 4 Peraturan Menteri Negara Agraria / Kepala Badan Pertanahan Nasional No. 3 Tahun 1997 tentang Ketentuan Pelaksanaan Peraturan Pemerintah No. 24 Tahun 1997 tentang Pendaftaran Tanah hingga saat ini, sebagai hukum positif di Indonesia yang mengatur pembuatan Surat Keterangan Waris, tidak hanya didasari pada sejarah politik hukum pertanahan yang telah peneliti jabarkan diatas, disisi yang lain sejarah, serta latar belakang dari muncul, dan masih diakuinya Surat Keterangan Waris itu sendiri sangat krusial keberadaannya, menjadi salah satu faktor penting lainnya masih diadopsinya aturan hukum masa kolonial Belanda di produk hukum nasional kita, yang dengan jelas masih mencerminkan isi dari Pasal 163 Indische Staatsregeling.

Para ahli hukum di negeri ini sepakat bahwa dengan belum terbentuknya kodifikasi Hukum Waris di Indonesia juga berdampak pada masih belum adanya aturan yang jelas, dan aturan yang bersifat nasional terkait pengaturan pembuatan Surat Keterangan Waris. Peraturan-peraturan yang mengatur atau menyinggung mengenai pembuatan Surat Keterangan Waris disepakati oleh para ahli hukum sebagai hasil peninggalan produk hukum kolonial penjajahan Negara Belanda di Indonesia. Masih diterapkannya konsep penggolongan penduduk di Indonesia, khususnya terkait dengan pembedaanpihak-pihak yang berwenang dalam pembuatan surat keterangan waris tidak bisa dipisahkan pada konsep dimana hukum waris di Indonesia hingga saat ini masih bersifat pluralistik, dimana hal tersebut merupakan pengaruh nyata dari Pluralisme Hukum Waris di Indonesia. Pluralisme Hukum Waris di Indonesia yang masih begitu kuat hingga sekarang dapat dilihat dengan masih dikenalnya hukum waris yang beranekaragam yang secara bersama-sama mengatur terkait sistem hukum pewarisan di tengah-tengah masyarakat Indonesia. Dalam 
perkembangannya Pluralisme Hukum Waris di Indonesia sudah seharusnya selaras dengan prinsip-prinsip dasar yang disyaratkan untuk terciptanya Pluralisme Hukum.

Kepastian hukum dalam bidang hukum waris yang belum tercapai salah satu faktor utamanya adalah masih tingginya tingkat pluralisme hukum pada hukum waris yang terdapat di Indonesia hingga saat ini, yang meliputi hukum waris Adat, hukum waris Islam, dan hukum waris BW. Dalam perkembangannya meskipun $\mathrm{BW}$ belum pernah dicabut keberlakuannya, telah timbul banyak penolakan dari sebagian besar masyarakat Indonesia, yang tidak setuju BW diterapkan bagi bangsa Indonesia, yang mana BW dianggap telah tidak sesuai dengan budaya dan kesadaran hukum masyarakat di Indonesia pada umumnya. Berdasarkan Garis-Garis Besar Haluan Negara yang pernah ditetapkan di Indonesia pada tahun 1978, 1983, 1988, dan 1999 terdapat semangat pembaharuan hukum secara terarah dan terpadu dengan jalan membentuk kodifikasi dan unifikasi hukum dalam beberapa bidang tertentu, guna tercapainya pembinaan hukum. Penyusunan serangkaian peraturanperUndang-undangan yang baru juga dibutuhkan untuk mendukung pembangunan sistem hukum yang lebih tertata guna mencapai tujuan hukum, salah satunya kepastian hukum. Mengakui dan menghormati hukum agama dan hukum adat merupakan salah satu unsur yang penting dalam membangun sistem hukum yang sesuai dengan budaya bangsa Indonesia. Konsep penggolongan penduduk di Indonesia sampai hari ini masih mempengaruhi dasar hukum pembuatan Surat Keterangan Waris tidak hanya terdapat pada Pasal 111 Ayat (1) Huruf C Angka 4 Peraturan Menteri Negara Agraria / Kepala Badan Pertanahan Nasional No. 3 Tahun 1997 tentang Ketentuan Pelaksanaan Peraturan Pemerintah No. 24 Tahun 1997 tentang Pendaftaran Tanah.

\section{Kepastian Hukum Bagi Warga Negara Indonesia Dalam Pembuatan Surat Ket- erangan Waris}

Usaha-usaha menghapus pengaruh hukum kolonial tidaklah mudah, dan dalam keadaan yang dapat dilihat saat ini masih terdapat hukum positif di Indonesia yang masih didasarkan oleh unsur-unsur hukum kolonial, yaitu salah satunya adalah masih dikenalnya pembedaan pihak-pihak yang berwenang membuat Surat Keterangan Waris di Indonesia yang dibedakan berdasarkan masing-masing golongan penduduk. Dalam kenyataannya usaha untuk menghapus pengaruh hukum kolonial tersebut berakhir dengan pengakuan bahwa proses realisasinya ternyata tidak sesederhana model-model strategiknya dalam tataran doktrin 6 .

Pada masa awal kemerdekaan Indonesia, terdapat perdebatan diantara para ahli-ahli hukum bersama dengan para pemangku kepentingan (stakeholder) terkait dengan apakah sistem hukum kolonial dalam beberapa aspek masih dapat dipergunakan, termasuk terkait dengan masih dipergunakannya Kitab Undang-Undang Hukum Perdata (KUHPerdata)/ Burgerlijk Wetboek voor Indonesie (BW) yang merupakan produk hukum masa kolonial pemerintahan Hindia-Belanda, khsusunya terkait dengan pembuatan Surat Keterangan Waris di Indonesia. Munculnya berbagai macam peraturan perundang-undangan yang telah mengatur terkait dengan pencabutan dan/ atau penghapusan beberapa ketentuan yang sebelumnya diatur dalam Burgerlijk Wetboek voor Indonesie (BW) adalah bentuk usaha penyelerasan hukum kolonial dengan kondisi masyarakat di Indonesia. Burgerlijk Wetboek voor Indonesie (BW) saat ini berlaku bagi bangsa Indonesia sepanjang tidak bertentangan dengan Undang-Undang Dasar Negara Republik Indonesia Tahun 1945, Pancasila, serta Peraturan Perundangundangan yang $\mathrm{ada}^{7}$.

${ }^{6}$ Soetandyo Wignjosoebroto. (1994). Dari Hukum Kolonial Ke Hukum Nasional-Dinamika Sosial-Politik dalam Perkembangan Hukum di Indonesia, Jakarta: PT Raja Grafindo, hlm. 13 .

Sudikno Mertokusumo. (2013). Mengenal Hukum Sebuah Pengantar, Yogyakarta: Cahaya Atma Pustaka, hlm. 3. 
Masih diberlakukannya aturan terkait pembedaan pihak-pihak yang berwenang membuat Surat Keterangan Waris di Indonesia yang masih didasarkan pada konsep penggolongan penduduk di Indonesia telah bertentangan dengan dasar negara, ideologi negara, termasuk peraturan-peraturan lain yang ada di Indonesia yang sudah tidak lagi mengenal adanya pembedaan golongangolongan penduduk di Indonesia. Pasal 111 Ayat (1) Huruf C Angka 4 Peraturan Menteri Negara Agraria / Kepala Badan Pertanahan Nasional No. 3 Tahun 1997 tentang Ketentuan Pelaksanaan Peraturan Pemerintah No. 24 Tahun 1997 tentang Pendaftaran Tanah yang masih menggunakan konsep penggolongan penduduk di Indonesia telah bertentangan dengan hukuk positif di Indonesia yang tidak lagi membeda-bedakan penduduk Indonesia.

Berdasarkan asas Lex posteriori derogat legi priori, peraturan yang baru mengalahkan, atau melumpuhkan peraturan yang lama, sehingga UU Kewarganegaraan RI, dan UU Adminduk yang disahkan sebagai Undangundang di tahun 2006 (UU Adminduk dengan revisi pada tahun 2013) menurut hukum bersifat lebih baru dibandingkan dengan aturan terkait pembedaan golongan penduduk di Indonesia yang tertuang dalam Pasal 163 Indische Staatsregeling (IS) yang diundangkan di Indonesia pada tahun 1925. Sehingga Pasal 163 Indische Staatsregeling (IS) yang masih mengenal pembedaan golongan penduduk di Indonesia secara hukum tidak berlaku lagi dengan lahirnya UU Kewarganegaraan RI dan UU Adminduk.

Berdasarkan sumber-sumber hukum primer, sekunder, maupun tersier yang telah dikumpulkan, yang kemudian dianalisa secara mendalam, dan dianalisa bahwa secara normatif hukum dogmatis telah terjadi konflik terkait masih diberlakukannya Pasal 111 Ayat (1) Huruf C Angka 4 Peraturan Menteri Negara Agraria / Kepala Badan Pertanahan Nasional No. 3 Tahun 1997 tentang Ketentuan Pelaksanaan Peraturan Pemerintah No. 24 Tahun 1997 tentang Pendaftaran Tanah. Konflik hukum tersebut diatas terjadi dimana UU Kewarganegaraan RI dan UU Adminduk yang termasuk dalam jenis dan hierarki PerturanperUndang-undangan menurut Pasal 7 Ayat (1) Undang-Undang Republik Indonesia Nomor 12 Tahun 2011 Tentang Pembentukan Peraturan PerundangUndangan secara hukum memiliki kekuatan untuk mengesampingkan, mendegradasi, dan menghapuskan keberlakuan dari Pasal 111 Ayat (1) Huruf C Angka 4 Peraturan Menteri Negara Agraria / Kepala Badan Pertanahan Nasional No. 3 Tahun 1997 tentang Ketentuan Pelaksanaan Peraturan Pemerintah No. 24 Tahun 1997 tentang Pendaftaran Tanah masih diberlakukan di negara ini. Peraturan Menteri Negara Agraria yang dikategorikan sebagai Peraturan Menteri secara hukum tidak masuk dalam jenis dan hierarki PerturanperUndangundangan (hierarki utama peraturan perundang-undangan) menurut Pasal 7 Ayat (1) Undang-Undang Republik Indonesia Nomor 12 Tahun 2011 Tentang Pembentukan Peraturan Perundang-Undangan.

Konflik hukum yang terjadi tersebut diatas telah menimbulkan ketidakpastian hukum bagi Warga Negara Indonesia dalam pembuatan Surat Keterangan Waris. Konflik hukum tersebut diatas dapat diselesaikan dengan "Asas Lex superior derogat lex inferior", yaitu apabila terjadi konflik hukum antara peraturan perundang-undangan yang lebih tinggi tingkatannya dengan peraturan perundang-undangan yang lebih rendah tingkatannya, maka peraturan perundangundangan yang lebih rendah tingkatannya dikesampingkan/ tidak diberlakukan.

Jika isi dari Pasal 111 Ayat (1) Huruf C Angka 4 Peraturan Menteri Negara Agraria / Kepala Badan Pertanahan Nasional No. 3 Tahun 1997 tentang Ketentuan Pelaksanaan Peraturan Pemerintah No. 24 Tahun 1997 tentang Pendaftaran Tanah ditelaah lebih dalam, dapat diketahui pula bahwa Peraturan Menteri tersebut menetapkan 3 (tiga) lembaga yang memiliki wewenang terkait pembuatan Surat Keterangan Waris di Indonesia. Lembaga pertama yang diberikan wewenang oleh Perturan Menteri tersebut adalah Lurah 
di Kelurahan atau Kepala Desa di Desa, yang diberikan wewenang untuk menyaksikan dan membenarkan isi dari Surat Keterangan Waris yang dibuat oleh Ahli Waris sendiri, yang kemudian dikuatkan oleh Camat di Kecamatan setempat. Lurah/Kepala Desa dan Camat memiliki wewenang yang diatur sedemikian rupa dalam Peraturan Menteri terkait pembuatan Surat Keterangan Waris bagi penduduk pribumi (asli Indonesia). Lembaga kedua yang diberi wewenang untuk membuat Surat Keterangan Waris oleh Pasal 111 Ayat (1) Huruf C Angka 4 Peraturan Menteri Negara Agraria / Kepala Badan Pertanahan Nasional No. 3 Tahun 1997 tentang Ketentuan Pelaksanaan Peraturan Pemerintah No. 24 Tahun 1997 tentang Pendaftaran Tanah adalah Balai Harta Peninggalan (selanjutnya disebut sebagai BHP), khususnya bagi WNI keturunan Timur Asing selain Tionghoa. BHP dalam perkembangannya mengalami pasang surut cakupan wilayah kerja, yang pada saat ini kantornya hanya terdapat di 5 (lima) kota besar di Indonesia, yaitu di Jakarta, Surabaya, Semarang, Medan, dan Ujung Pandang. Lembaga ketiga yang diberi wewenang untuk membuat Surat Keterangan Waris oleh Pasal 111 Ayat (1) Huruf C Angka 4 Peraturan Menteri Negara Agraria / Kepala Badan Pertanahan Nasional No. 3 Tahun 1997 tentang Ketentuan Pelaksanaan Peraturan Pemerintah No. 24 Tahun 1997 tentang Pendaftaran Tanah adalah Notaris, khususnya membuat Surat Keterangan Waris bagi penduduk golongan Eropa dan WNI keturunan Tionghoa.

Kepastian hukum yang tidak tercapai dengan masih diberlakukannya konsep penggolongan penduduk terkait pembuatan Surat Keterangan Waris sebagaimana diatur dalam Pasal 111 Ayat (1) Huruf C Angka 4 Peraturan Menteri Negara Agraria / Kepala Badan Pertanahan Nasional No. 3 Tahun 1997 tentang Ketentuan Pelaksanaan Peraturan Pemerintah No. 24 Tahun 1997 tentang Pendaftaran Tanah telah bertentangan dengan unsur yuridis dari lahirnya Peraturan Menteri tersebut itu sendiri, yaitu bertentangan dengan tujuan UUPA yang juga menjadi "grundnorm" atau "basic norm" dari tujuan dikeluarkannya Peraturan Menteri tersebut diatas, dimana dalam Penjelasan Umum UUPA BAB I disebutkan bahwa Tujuan Undang-Undang Pokok Agraria ialah:

a. meletakkan dasar-dasar bagi penyusunan hukum agraria Nasional, yang akan merupakan alat untuk membawakan kemakmuran, kebahagiaan dan keadilan bagi Negara dan rakyat, terutama rakyat tani, dalam rangka masyarakat yang adil dan makmur;

b. meletakkan dasar-dasar untuk mengadakan kesatuan dan kesederhanaan dalam hukum pertanahan;

c. meletakkan dasar-dasar untuk memberikan kepastian hukum mengenai hak-hak atas tanah bagi rakyat seluruhnya.

Ketidakjelasan aturan hukum terkait konsep penggolongan penduduk yang terdapat dalam Pasal 111 Ayat (1) Huruf C Angka 4 Peraturan Menteri Negara Agraria / Kepala Badan Pertanahan Nasional No. 3 Tahun 1997 tentang Ketentuan Pelaksanaan Peraturan Pemerintah No. 24 Tahun 1997 tentang Pendaftaran Tanah tersebut diatas telah menimbulkan ketidakpastian hukum. Kepastian hukum bagi Warga Negara Indonesia dalam pembuatan Surat Keterangan Waris dapat tercapai dengan lahirnya hukum yang mengatur terkait pembuatan Surat Keterangan Waris yang didasari pada moral bangsa Indonesia sendiri, yang tidak lagi mengenal adanya perbedaan golongan penduduk.

Kepastian hukum bagi Warga Negara Indonesia dalam pembuatan Surat Keterangan Waris sangatlah penting untuk ada, karena hukum itu tidak hanya bisa kita lihat dari segi keadilan dan kemanfaatannya saja, tetapi bagaimana dengan kepastian dari hukum itu sendiri ${ }^{8}$. Kepastian hukum tersebut menjadi salah faktor utama agar dapat menciptakan keadilan dan ketenteraman bagi kehidupan

${ }^{8}$ Diah Aju Wisnuwardhani. (2018). "Hukum Sebagai Sistem Norma". WIDYA YURIDIKA: Jurnal Hukum, Vol. 1 No. $1,29$. 
bangsa Indonesia, karena Kepastian Hukum merupakan sesuatu yang harus ada apabila keadilan dan ketenteraman hendak diciptakan, mustahil menciptakan keadilan dan ketenteraman apabila kepastian hukum tidak dipelihara dengan baik ${ }^{9}$.

\section{KESIMPULAN}

Terjadi ketidakpastian hukum bagi Warga Negara Indonesia dalam pembuatan Surat Keterangan Waris yang dasar hukumnya masih menerapkan konsep penggolongan penduduk. Semenjak diberlakukannya Undang-undang Nomor 12 Tahun 2006 Tentang Kewarganegaraan Republik Indonesia, dan Undang-Undang Republik Indonesia Nomor 24 Tahun 2013 Tentang Perubahan Atas Undang-Undang Nomor 23 Tahun 2006 Tentang Administrasi Kependudukan yang tidak lagi mengenal adanya penggolongan penduduk Indonesia, menurut hukum Pasal 111 Ayat (1) Huruf C Angka 4 Peraturan Menteri Negara Agraria / Kepala Badan Pertanahan Nasional No. 3 Tahun 1997 tentang Ketentuan Pelaksanaan Peraturan Pemerintah No. 24 Tahun 1997 tentang Pendaftaran Tanah tidak berlaku lagi pada saat ini.

\section{DAFTAR PUSTAKA}

\section{Buku}

Abdul Rachmad Budiono. (2005). Pengantar Ilmu Hukum, Malang: Bayumedia Publishing.

Mohd. Idris Ramulyo. (1996). Beberapa Masalah Pelaksanaan Hukum Kewarisan Perdata Barat (Burgerlijk Wetboek), Jakarta: Sinar Grafika.

Soedjono Dirdjosisworo. (2018). Pengantar Ilmu Hukum, Depok: PT. Raja Grafindo Persada.

Soetandyo Wignjosoebroto. (1994). Dari Hukum Kolonial Ke Hukum
Nasional-Dinamika Sosial-Politik dalam Perkembangan Hukum di Indonesia, Jakarta: PT Raja Grafindo.

Sudikno Mertokusumo. (2013). Mengenal Hukum Sebuah Pengantar, Yogyakarta: Cahaya Atma Pustaka.

Surini Ahlan Sjarif dan Nurul Elmiyah. (2014). Hukum Kewarisan Perdata Barat: Pewarisan Menurut Undang-Undang, Jakarta: Kencana Prenadamedia Group.

\section{Jurnal}

Diah Aju Wisnuwardhani. (2018). "Hukum Sebagai Sistem Norma". WIDYA YURIDIKA: Jurnal Hukum, Vol. 1 No. 1, 29.

Mohd. Idris Ramulyo. (1982). "Suatu Perbandingan antara Ajaran Sjafi'I dan Wasiat Wajib di Mesir, tentang pembagian Harta Warisan untuk Cucu Menururt Islam”. Majalah Hukum dan Pembangunan No. 2 Thn. XII,154.

\section{Undang-Undang}

Peraturan Menteri Negara Agraria/ Kepala Badan Pertanahan Nasional No. 3 Tahun 1997 tentang Ketentuan Pelaksanaan Peraturan Pemerintah No. 24 Tahun 1997 tentang Pendaftaran Tanah.

${ }^{9}$ Abdul Rachmad Budiono. (2005). Pengantar Ilmu Hukum, Malang: Bayumedia Publishing, hlm. 22. 